\title{
On the Third Power: Taking Independence of the Judiciary Seriously
}

\author{
The greatest scourge an angry heaven ever \\ inflicted upon an ungrateful and a sinning \\ people was an ignorant, a corrupt, or \\ a dependent judiciary. \\ John Marshall
}

\section{On the Independence of the Judiciary}

The judiciary is the third branch of the government (the third state power) with the responsibility of applying the laws to specific cases and settling all disputes. The independence of the judiciary according to Parmatma Sharan "is a corner stone of ever democratic government and upon it is built the structure of civil liberty. This structure is destroyed, the moment, the judiciary becomes susceptible to political pressure."1

The organization of the judiciary must be based on the following features: the appointment of only highly qualified and experienced judges; the method of appointing judges must be fair, systematic, effective and transparent; the method of removing judges should be difficult; no single entity should have the power to remove judges; nevertheless, this does not mean that judges should be untouchable.

A worse state of things (Michel Montaigne would surely would agree including with regard to the judiciary) cannot be imagined than "where wickedness comes to be legitimate, and assumes, with the magistrates' permission, the cloak of virtue (...) The most extreme sort of injustice, according to Plato, is where that which is unjust should be reputed for just. The common people then suffered very much (...)."2

\footnotetext{
1 P. Sharan, Comparative Government and Politics, New Delhi 1976, p. 400.

2 Essays of Michel de Montaigne, ed. W.C. Hazlitt, trans. Charles Cotton, London 1877, book III, chapter XII, p. 916.
} 


\section{Images and Parallels: In the Name of the Crown or of the People?}

\section{Francis Bacon's Bright Side: Most Gifted Mind of the English Renaissance}

Francis Bacon (1561-1626) in his essay Of Judicature in 1612 wrote in a very elegant and convincing style:

Judges ought to remember, that their office is jus dicere, and not jus dare, to interpret law, and not to make law, or give law. (...) Judges ought to be more learned than witty; more reverend than plausible; and more advised than confident. Above all things, integrity is their portion and proper virtue.

A judge ought to prepare his way to a just sentence, as God used to prepare his way, by raising valleys and taking down hills: so when there appeared on either side an high hand, violent prosecution, cunning advantages taken, combination, power, great counsel, then is the virtue of a judge seen, to make inequality equal; that he may plant his judgment as upon an even ground.

One foul sentence doth more hurt than, than many foul examples. For these do but corrupt the stream, the other corrupted the fountain. So with Solomon, Fons turbatus, et vena corrupta, est justus cadens in causa sua coram adversario. A righteous man falling down before the wicked is as a troubled fountain or a corrupt spring. ${ }^{3}$

\section{Francis Bacon's Dark Side: Highest Judicial Officer in England, but...}

Later on, in 1618, Francis Bacon became Lord Chancellor, the highest judicial officer in England. But by 1621 all honors came to a halt. ${ }^{4}$ As Lord Chancellor, he was impeached by the House of Commons for accepting bribes. ${ }^{5}$ Bacon, a lord himself, had hopes that the House of Lords, where impeachments were tried, would end the matter quietly by accepting his resignation. But the Lords refused, demanding a trial on the charges or a complete confession. Desiring above all to avoid full exposure, Bacon offered a compromise - a guilty plea but no details.

It rested therefore that, without fig-leaves, I do ingenuously confess (...) And, therefore, my humble suit to your Lordships is that my penitent submission may be my sentence, and the loss of the seal my punishment; and that your Lordships will spare any further sentence.

3 "Of Judicature LVI", Essays of Francis Bacon. The Essays or Counsels, Civil or Moral, of Francis Ld. Verulam, www.authorama.com/essays-of-francis-bacon-56.html (accessed: 2020.08.01).

4 J. Borkin, The Corrupt Judge. An Inquiry into Bribery and Other High Crimes and Misdemeanors in the Federal Courts, New York 1962, pp. 4-5.

5 Ibidem, p. 4., "The articles of impeachment and the confession reveal a corruption so gross that one wonders how it went undetected for three years. The Lord Chancellor 'shook down' the French 'vintners,' using the power of his office to threaten their imprisonment; they were compelled to pay 'or else.'In some cases he took bribes from both litigants. (...) Bribes reached him in minute driblets as well as in sizable packages." 
In his own defense, Bacon, although he admitted the bribes, asserted that they never influenced the final decision, that sometimes he decided against the briber, and that his decisions, once delivered, were never recalled. But he conceded that, even if he were the "justest chancellor, this was the justest censure in Parliament."

Bacon was fined forty thousand pounds, a monumental sum, and "imprisoned in the Tower during the King's pleasure." He was also barred forever from holding any office in the "State or Commonwealth," from sitting in Parliament or from coming "within the verge of the court."

A few days after his imprisonment, King James liberated him from prison. In addition it should be emphasized here that Bacon defended the royalist point of view when he wrote,

when kings and states do often consult with judges; and again, when judges do often consult with the king and state: the one, when there is matter of law intervenient in business of state; the other when there is some consideration of state intervenient in matter of law.

\section{Edward Coke: From the Chief Justice of Common Pleas to the Tower}

In comparison - the subordination of the judicature to the royal will was strongly resisted by Chief Justice Sir Edward Coke (1552-1634), Bacon's great rival, who refused to comply with James I's wishes in a number of cases in which the royal prerogative was involved. In 1606 he was appointed Chief Justice of Common Pleas, and in this post he began to come into a conflict with James I. The first instance occurred in 160708 when King James attempted to assert his personal right to tax imports and exports. Coke declared this to be unlawful, arguing that the power of taxation rested only in Parliament. In a series of similar decisions, Coke resisted Archbishop Bancroft's claim, which James I favored, to the authority to remove certain church cases from the jurisdiction of the common-law courts (1606-1609). In 1610 Coke decided against the King's authority to make law by proclamation, and in 1611 he resisted Archbishop Abbot's attempt to remove ecclesiastical cases to the Court of High Commission. ${ }^{6}$

After the Crown dismissed him from the position of Chief Justice, Coke continued to resist. He criticized the Crown's marriage into the Catholic Spanish royal family, denounced interference with the liberties of Parliament, and served on the committee to impeach Francis Bacon. For these actions he was sent to the Tower in 1622. On his release he entered Parliament, and from there opposed King Charles I's demand for subsidies.

\section{Recent Files From the Slovak Republic}

In an event earlier this year, the National Criminal Agency in the Slovak Republic staged an intervention called "Storm" and initiated the prosecution of corrupt judges

6 Sir Edward Coke (1552-1634). Online Library of Liberty, https://oll.libertyfund.org/pages/coke-siredward-1552-1634 (accessed: 2020.08.01). 
and prosecutors. The Constitutional Court had in a non-public plenary session on 12 March 2020, decided on the request of the Prosecutor General for consent to take into custody 13 judges of the district and regional courts and the Supreme Court and adopted the proposal for further action. In the case of five of them, it gave consent for taking them into custody.

In May 2020, the first judge of the Constitutional Court stepped down from his post "because of health reasons and his age close to that of retirement" after being confronted with suspicious contacts with a major criminal on trial.

As of early June 2020, the former Prosecutor General was being investigated in hearings before the Disciplinary Commission at the Office of the recent Prosecutor General because of accusations of corruption and abuse of power while in office.

Are these signs not enough to indicate that the "fountain is troubled and the spring is corrupt?"

\section{Historical Background (twentieth century) and Heritage}

Some years ago, Ronald Dworkin repeatedly expressed his view about the role of judges:

In the decades after World War II more and more of democracies gave judges new (...) and unprecedented powers to review the acts of administrative agencies and officials under broad doctrines of reasonableness, natural justice and proportionality, and then even more surprising powers to review the enactments of legislatures to determine whether the legislatures had violated the rights of individual citizens laid down in international treaties and domestic constitutions. ${ }^{7}$

People who are trying to defend and to pursue their rights usually place high expectations on the judiciary (judges and courts) and it its impartiality and independence. ${ }^{8}$

The opening formula of the judgment shows the position of the judiciary and expresses its legitimation within the existing understanding the constitution. ${ }^{9}$ The formula "In the name of the Slovak Republic," which opens every judgement made by the Slovak courts, should not be misunderstood or overestimated, but it at least leads to some, less formal, questions of interest. Does it make any differences for a judgment to be pronounced in the name of the republic, i.e., in the name of the state and not of the people? What does it mean from the point of view of the content of a judgment?

7 R. Dworkin, "The Judge's New Role: Should Personal Convictions Count?," Journal of International Criminal Justice 2003, vol. 4, p. 5.

8 A. Bröstl, "At the Crossroads on the Way to an Independent Slovak Judiciary" [in:] Systems of Justice in Transition. Central European Experiences since 1989, eds J. Přibáň, P. Roberts, J. Young, Hampshire 2003, chapter 9, p. 141 (162).

9 See especially: P.C. Müller-Graff, "Zur Geschichte der Formel 'Im Namen des Volkes"' [in:] Journal of the Law of the Civil Procedure 1975, vol. 88, p. 442.; J. Limbach, "Im Namen des Volkes." Macht und Verantwortung der Richter, Stuttgart 1999, p.105. 
Is there a relevant change towards a stabilized judiciary in post-communist countries such as the Slovak Republic ${ }^{10}$

The main difference between the totalitarian state (whether referred to as "communist" or "socialist") and the pluralist and democratic state governed by the Rule of Law lies in the answer to, and solution of, the question of the concentration and separation of state power. The violent regimes of the twentieth century have confirmed James Madison's basic truth in The Federalist, which was inspired by Montesquieu's ideas: "The accumulation of all powers, legislative, executive, and judiciary, in the same hands whether of one, a few, or many, and whether hereditary, self-appointed or elective, may justly be pronounced the very definition of tyranny."11

However, the judiciary was considered to be the "weakest" power in communist Czechoslovakia, in the sense that it was not empowered or intended to be a real, independent power to prevent the fundamental rights and freedoms of citizens. Its main task, especially after 1948, was to be primarily an instrument to protect the state and to be an agent of repression, as an effective threat against the enemies of the "people's democratic, socialist" state and its legal order. The social status and the prestige of the judges were so damaged that it was possible for almost anyone to become a judge. The standard requirements were very low - a minimum of only a one-year course to become a professional judge. A political examination was the first and most important subject designed to install cadres, i.e., politically reliable people, as judges. Nobody who failed the first part was allowed to proceed to the examination on professional subjects (constitutional law, criminal law, civil law, etc.). ${ }^{12}$

The courts were used as a cog in the totalitarian machine, and the judges were considered, and instructed to be no more than "servants whose obligation is to fulfil the will of the current power-holders and to accept the decisions of state administrative officials without reservation."

The system of the judiciary is based on the ideals of the all-powerful and all-deciding impact of Marxism-Leninism in all branches of social life including the judicial application of the law. ${ }^{13}$

The period 1948-68 can be summarized in the words of a former judge in a book about his personal judicial experience in Czechoslovakia after 1948:

It is unrealistic to expect an orgasm to last for twenty years. Determination turns into improvisation, zeal into hypocrisy, and the Marxist Writ becomes as impractical and misplaced a source of inspiration as a Gideon Bible in a brothel. ${ }^{14}$

\footnotetext{
10 A. Bröstl, "At the Crossroads...," p. 141.

11 J. Hamilton, J. Madison, J. Jay, The Federalist. American State Papers, Chicago 1958, p. 153; also see: Ch. Montesquieu, Oeuvres completes, Paris 1875, p. 152.

12 A. Bröstl, "At the Crossroads...," p. 143.

13 Z. Kühn, "Ideologie aplikace práva v době reálného socialismu" [in:] M. Bobek, P. Molek, V. Šimíček, Komunistické právo v Československu. Kapitoly z dějin bezpráví, Brno 2009, p. 89.

14 O. Ulč, The Judge of A Communist State, Ohio 1972, p. 306.
} 
The most tragic paradox was that it was considered, from the viewpoint of the communist regime, the greatest arrogance for a citizen to ask a court to protect his or her rights or freedoms, even though they were formally protected in the constitution. Thus, at the turning point of the Velvet Revolution in 1989 frustration had built up. Subsequently, one of the first revolutionary demands was to put an end to the period of legal nihilism that had made a mockery of human values, justice, and the supposed weakness of the citizen as an individual, with contempt for law and the legal order, because what counts is that degree to which judges have (or have not) served as protectors of human rights and freedoms.

Article 142 section 3 of the Constitution of the Slovak Republic 1992 states that "decisions are declared in the name of the Slovak Republic" although there was a brief discussion on the subject during drafting of the amendment of the Constitution in 2001. ${ }^{15}$ Does the power of the state not originate from the people or the citizens? Should this not be mentioned in the preamble to every court decision? As a matter of fact, the state (the Slovak Republic) is often a party in court proceedings. From this point of view, it is very odd to declare decisions in the name of one participant, not even taking into consideration its success or failure in the proceedings.

Corruption is, in fact, doing partial justice, a consent to "justice" in favor of one of the parties that is following its reasons and arguments. ${ }^{16}$

In 2003, after the first decade of the independent Slovak Republic and the efforts to establish an independent judiciary passed, I wrote:

No doubt, the first one hundred years of freedom or the journey on the road to freedom and to the introduction of a state, which may be called a "state of judicial independence," will be the most difficult. ${ }^{17}$

\section{You Will Know Them by Their Fruits}

The aim of the judiciary is to restore social peace through their judgments, which is not an easy task, especially given the expectations of the parties in individual cases. ${ }^{18}$ What is the ideal of a fair and just judge? How is it possible to find such a person? Here we are back again touching on the opening point of our discussion regarding the decisional (personal) independence of judges.

The judges' sense of justice must (...) be universalized. He, no less than the juryman, is a reasonable man, his sense of justice is that of the bonus paterfamilias. He must avoid idiosyncrasies, his views of right and wrong must conform to a practical standard, he must not

\footnotetext{
15 P. Rohárik, “Ústavná garancia nezávislosti súdnej moci”, 5 Justin 1999, no. 2, pp. 51-53.

16 In the Name of the People (Renmin de mingyi) is also the title of the 2017 Chinese TV drama (anticorruption drama) series based on the web novel of the same name by Zhou Meisen. Its plot revolves around a prosecutor's efforts to unearth corruption in a present-day fictional Chinese city.

17 A. Bröstl, "At the Crossroads...," p. 157.

18 J. Limbach, "Im Namen des Volkes...," p. 89.
} 
be governed by mere psychological or ethical theories however attractive they may be. It is justice as it appears to the reasonable man, the good citizen that he must administer. ${ }^{19}$

In the wording of art. 141 of the Constitution of the Slovak Republic the judiciary in the Slovak Republic shall be administered by independent and impartial courts. As a part of the judiciary the Constitutional Court is defined in art. 124 of the Constitution as an independent judicial authority vested with the mandate to protect constitutionality.

The Constitutional Court shall be composed of thirteen judges. The judges of the Constitutional Court are appointed by the President of the Slovak Republic for a twelve-year term as proposed by the National Council. The National Council shall propose the double number of candidates for judges that shall be appointed by the President (art. 134, section 1 and 2 of the Constitution).

After almost 30 years of experience, there is a lack of answers to fundamental questions that remain undecided:

a. How to safeguard that the best candidates for the position of an independent judge of the Constitutional Court are proposed by the National Council, and after that appointed by the President?

b. What role do security examinations of the candidates for judges of the ordinary courts play within their nomination procedure? What may become the subject of a security examination? Maybe another question comes first into the mind: Should security examinations of judges take place in a state under the Rule of Law in general?

c. Focusing on the Constitutional Court as the highest judicial authority: can a constitutional amendment be challenged before the Constitutional Court at all, and may it be declared unconstitutional?

Point a. It is clear that there will be a battle between political parties on nominations in the National Council, and especially when it concerns nine of the 13 judges on the bench (for the third time in the history of the Constitutional Court). If there is a simple majority in the National Council needed to elect candidates (the double number of vacancies) for judges of the Constitutional Court, and if the result is further elaborated by a President who is not in the position of a pouvoir neutre, it can happen that the Constitutional Court will look "unicolored." The safety catch to prevent such an outcome - and it was signalized many years ago also by former judges of the Constitutional Court - is, for instance, to amend the constitutional rule in art. 84 section 4 of the Constitution to the following wording:

For the purpose of adopting or amending the Constitution, a constitutional law (...) for electing the list of candidates for the position of a judge of the Constitutional Court (in case of vacant seats), which shall be submitted to the President (...) the consent of three fifths majority of all Members of the Parliament shall be required.

$\overline{19}$ A. Barak, Judicial Discretion, New Haven 1989, p. 125. 
In my opinion, this would collaterally enable leaving out the second sentence of art. 134 section 2 (on proposing the double number of candidates by the National Council) as being superfluous.

With regard to b. and c., after heavy criticism from many corners on the state of the judiciary, the Government in 2014 announced proposed changes even in the constitutional framework of it. One main amendment dealt with tightening conditions for access to the judicial function and the use of security examinations by the National Security Office in hearings before the Judicial Council. These proposals had to clarify questions as to whether the candidates for judges of ordinary courts are, e.g., financially independent and what their property relationships are, but also help to reveal any links to organized crime or drug trafficking.

The Finding of the Constitutional Court No. PL. ÚS 21/2014 adopted on 30 January 2019, shortly before the term of the nine judges of the Constitutional Court expired, which was on the proposal of the President of the Judicial Council, declared in noncompliance with art. 147 section 1, last sentence, and of art. 154d section 1 to 3 of the Constitutional Act No. 161/2014 Coll. (by which the Constitution was amended) with art. 1 section 1, art. 141 section 1, and art. 144 section 1 of the Constitution itself (both articles deal profoundly with the principles of the Rule of Law-State) on the security examinations of judges of ordinary courts (in an ex-post-facto and also in a normal perspective) and also the candidates for appointments to become judges.

The finding in this case pending since 2014 was seen as a breakthrough in the Rule of Law doctrine as it had been interpreted to date, because it declared for the first time constitutional amendments or acts as being unconstitutional. ${ }^{20}$ The idea of unconstitutional Constitutional Amendments is not unusual. "When Constitutions empower the Constitutional Authority to amend the Constitution it means that they only admit (acknowledge) them the right to change the Constitution, not to abrogate or to remove it. ${ }^{21 "}$

The conclusion and the voice of the opinion of the majority was based on the reasoning and on the argument that the intended amendment of the Constitution does not respect the principle of the separation of powers (as a constitutional principle) and that is why it violates with a decisive constitutional intensity the material core of the Constitution.

The principles of a democratic state and the Rule of Law state that they create the material core of the Constitution and as key (constitutional) constitutive values are

20 Compare with considerations on the topic in Y. Roznai, Unconstitutional Constitutional Amendments. The Limit of Amendment Powers, Oxford 2017, pp. 15, 105 and 179; R. Alexy, "Constitutional Rights and Constitutional Review," published at www.pravvni-edu.rs/conferencje/2014.10.24\%Funda mental\%20Rights/Alexy.pdf (accessed: 2020.08.01).

21 See K. Hesse, Grundzüge des Verfassungsrechts der Bundesrepublik Deutschland. 20. Auflage, Heidelberg 1999, Rdn. 692; R. Thoma, “Die juristische Bedeutung der grundrechtlichen Sätze der deutschen Reichsverfassung in allgemeinen" [in:] Die Grundrechte und Grundpflichten der Reichsverfassung, ed. C. Nipperdey, Bd. I, 1929, p. 1 (p. 39). 
untouchable and create the basic criterion of the constitutional review of any decision of an authority of public power. ${ }^{22}$

In our opinion announced as early as in $2008^{23}$ (this case appeared in 2014) unconstitutional or non-constitutional laws (in fact and by name Constitutional Acts of the National Council), which can become the object of examination by the Constitutional Court, do exist. The Constitutional Court in a narrow, literal sense decides only on the compliance of ordinary laws (statutes, Acts of the National Council) with the Constitution (when reading art. 125 section 1 Letter a/ of the Constitution). There is not an expressis verbis mentioned special power belonging to this authority concerning Constitutional Acts and their compliance or non-compliance with the Constitution. It can be considered as a gap that can be bridged by (an activist?) interpretation (Constitutional Acts are special Acts of the parliamentary body passed by a qualified majority and they also can be included into the scope of examinations on compliance in art. 125 of the Constitution). In accomplishing this consideration, it should also be added that the Constitutional Court is the only body (constitutional authority) that may interpret the Constitution and Constitutional Acts (provided for by art. 128). ${ }^{24}$

However, the form of a Constitutional Act should not become (and not be used as) a gold-leaf for covering up unconstitutional content, because this clearly results in the violation of constitutional principles, i.e., the principles of the Rule of Law. ${ }^{25}$

Thus, the decisive question here is whether the National Council in the capacity of the "Constitution-maker" touches the untouchable material core of the Constitution (in other words a "set of Rule of Law principles"), or - to borrow the expression from Yaniv Roznai, the doctrine of whom the Constitutional Court is following in the finding above - "the Genetic Code of the Constitution." The concrete principles touched on and concerned here were the principle of the separation of powers and the connected principle of checks and balances and the independence of the judiciary.

If we conclude that the majority opinion is based on the declaration of the violation of the principles of the Rule of Law (mentioned in the articles of the Constitution), and in this respect especially pointing out the violation of the material core of the Constitution, because, plainly speaking, two public authorities belonging to the executive power (the Judicial Council and an "authority fulfilling tasks concerning the protection

\footnotetext{
22 The principles of a democratic state based on the Rule of Law are for the first time mentioned in the Finding of the Constitutional Court of the Slovak Republic PL. ÚS 16/95 of 24 May 1995 [in:] Collection of Findings and Resolutions of the Constitutional Court of the Slovak Republic 1995, Košice 1996, p. $38 \mathrm{ff}$.

${ }^{23}$ A. Bröstl, "O ústavnosti ústavných zákonov" [in:] Metamorfózy práva ve strední Evropě. Zborník z mezinárodní konference ve Znojmě, eds H. Jermanová, Z. Masopust, Praha-Plzeň 2008, pp. 11-24. The leading sentences of the majority opinion are based on the theory presented recently by Y. Roznai [in:] idem, Unconstitutional Constitutional Amendments..., the views of whom are presented and cited relevantly in the respective Finding of the Constitutional Court.

24 Compare: On the Law Amending art. 125 of the Constitution. Ruling of the Constitutional Court of the Republic of Lithuania of 24 January 2014, https://www.Irkt/lt/en/court-acts/search/170/ta850/ summary (accessed: 2020.08.01).

25 A. Bröstl, “O ústavnosti ústavných zákonov...," pp. 11-24.
} 
of national security," i.e., a constitutionally vaguely determined authority which shall screen judges), should decide on the ability of judges to hold judicial positions. ${ }^{26}$ On a more abstract level, the Constitutional Court concluded that the Constitution contains an implicit material core; its basis is composed from the principles of the democratic state and the state Ruled by Law, among them the principle of separation of powers and the principle of the independence of the judiciary. To underline the main idea: in this context Constitutional Acts should not contradict the material core of the Constitution.

We should remember that in a Finding from 1995 the Constitutional Court stated:

(...) also the legislative authority is without any doubts bound by the Constitution and its principles, the changing of which the Constitution does not permit, because of their constitutive importance for the democratic nature of the Slovak Republic as it is declared in art. 1 of the Constitution. ${ }^{27}$

\section{Is a New Wind of Change Blowing in the Slovak Judiciary?}

The main goals declared in the Program Declaration of the new Government (in office since March 2020) ${ }^{28}$ are to renew the credibility of the judiciary by stopping corruption and cleaning up the courts and prosecutors' offices. ${ }^{29}$

\footnotetext{
26 There was dokimasia in ancient Athens, and it was the name of the process of ascertaining the capacity of the citizens for the exercise of public rights and duties. The examination was carried out in public by the archons in the presence of the boule, and anyone present had the right to raise objections. As far as we followed the recent development concerning the topic of security examinations of the Judges, we realized that the Freistaat Bavaria (statement of the Bavarian Regional Government from September 2016) decided in the future to examine all new judges from the point of view of their fidelity to the Constitution (Bavaria has a special Free-State of Bavaria Constitution). It introduced the so-called Regelanfrage, which is an examination by the Office of the Protection of the Constitution (Verfassungsschutzamt). The aim is to prevent cases like the one concerning the appointment of B. Maik to a judicial function. In 2014 it was shown that this judge for a temporary period in Lichtenfels (Amtsgericht Lichtenfels) was a long-term active right extremist and a member of an anti-Semitic band Hassgesang (Hate Singing). The Bavarian Minister of Interior proposed examinations for all officials in public service, but it was decided that this will be reserved only for judges.

27 Finding No. PL. ÚS 16/95 of 24 May 1995 concerning, among other things, the status of the National Council (originally p. 5 of the Finding).

28 The new coalition in power is composed of four political parties: Ordinary People and Independent Personalities (OL'ANO, 25.02\%), We Create a Family (SME RODINA, 8.24\%), Freedom and Solidarity (Sloboda a Solidarita, SaS), For the People (Za ludí, 5.77 \%).

29 One general remark: in the line with domestic reports and statistical data and according to the report of Transparency International Slovakia of 2019, the number of the judges in Slovakia had reached a historical maximum of 1350 (it has even increased in 2020 to 1370 judges). In 2016-17, 186 judges left their positions, mainly because of the age limit, but also for other reasons. This means the same number of judges should come in, chosen in a comparatively more transparent proceedings (public hearings and evaluations).
} 


\section{Judicial Council}

Because of the bad experiences with the model of the Judicial Council introduced by Constitutional Amendment 90/2001 Code of Laws, the reforms should first of all concern the composition of this body. The problem is the recall and exchange of its members when there is a change in the Government or in the person of the President (the unified opinion of the plenary of the Constitutional Court is in favor of not-recalling the members of the Judicial Council when there is a change in the Government or the President). Keeping in mind the balance of the composition of the Judicial Council (the original idea), there are efforts to adopt a rule with a clear message that the legislative power and executive power should always nominate candidates or members who are not judges. Currently, a new attempt to elect a new President of the Supreme Court following a reshuffling of Judicial Council personnel as a relevant electoral body has just been successfully accomplished. ${ }^{30}$

It is expected that the Judicial Council will be assigned a new duty to introduce preventive measures against installing unreliable persons as judges (including examinations concerning the property relations of all judges). This will also take into consideration the surplus of property of their relatives, including examinations on the general reliability of judges, the property examinations of whom raise reasonable doubts in the minds of the members of the Judicial Council regarding the legality of how their property was acquired. The Judicial Council must be equipped with the appropriate tools to conduct these examinations.

\section{Constitutional Court}

Finally, reform concerning the composition of the Constitutional Court is planned. It should include checks against the passivity of the National Council in the case when no candidates for judges of the Constitutional Court are elected, and at the same time checks preventing the concentration of power in the hands of one political representation. The candidates should be elected through a public procedure focusing on their moral and professional standing. Proposed measures should also include a retirement age not only for the judges of the ordinary courts (65 years without any exception) but for the first time, for judges of the Constitutional Court (70 years of age).

Concerning another competence of the Constitutional Court, it is agreed that it is not necessary to ask the Constitutional Court to give consent to taking a judge into custody.

\footnotetext{
30 The Judicial Council of the Slovak Republic consists of 18 members. According to art. 141a of the Constitution the members are: a. nine judges elected and recalled by the judges of the Slovak Republic; b. three members elected and recalled by the National Council of the Slovak Republic; c. three members appointed and recalled by the President of the Slovak Republic; $d$. three members appointed and recalled by the Government of the Slovak Republic.
} 


\section{Supreme Administrative Court}

Another main task, and a de facto step anticipated for quite a long time concerning the judiciary, is to establish the Supreme Administrative Court of the Slovak Republic as a new judicial authority (among others with the competence to become a disciplinary court for judges, prosecutors, and other members of the legal profession instead of the Constitutional Court), which may help to unburden the Constitutional Court.

\section{Responsibility of Judges}

From the traditional point of view expressed in valid laws, judges cannot be prosecuted for their decisions, i.e., opinions presented in judgements are revised, and their decision-making becomes the subject of critical review. Amendments to the Criminal Code also directed at certain behaviors of judges and prosecutors are considered to be necessary, following the example of the Austrian model. Thus, introducing the crime of Anfütterung (sweetening) is also believed to affect the corrupt behaviour of judges in which the connection between taking a bribe and behaving in contradiction with one's duties is not evident or provable or capable of being proved..$^{31}$ The possibility of introducing into the Criminal Code the crime of the perversion of justice, or Rechtsbeugung, known from the German legal order and experience will also be discussed and considered. ${ }^{32}$

\section{Specialization of Judges, Unreasonable Delays}

The specialization of judges, which was ignored by former Heads of the Judiciary, will be supported as will the participation of the public in the selection boards and procedures. The Government is ready to enforce time frames for decision-making in individual matters or cases (designating time periods within which cases must be finished) and to continuously monitor courts, agencies, and judges. ${ }^{33}$

\footnotetext{
31 See the amendment of the corruption criminal law (Korruptionsstrafrechtsänderungsgesetz) in Austria which entered into force on 1 January 2013, and concerns par. 305-308 of the Criminal Law. In the sense mentioned above, it also contains the inspiring par. 307b on the "devotion of an advantage to take influence" (Anfütterungsverbot).

32 The Federal Court of Justice (Bundesgerichtshof) in judgement 2 StR 479/13 of 22 January 2014, declared its statement to the perversion of justice by judges and other civil servants (public officials). According to par. 339 of the German Criminal Code (Strafgesetzbuch) it concerns an arbitrary act of judges who intentionally and gravely veer away from the law and statutes, thus giving an advantage or disadvantage to one of the parties.

33 Regarding one interesting decision from Germany: unreasonable delay can be, in some cases, qualified as a perversion of justice. The Regional Court (Landgericht) of Rostock found in its decision that a judge of the Amtsgericht (Local Court) Güstrow who retired in 2018 because of illness was accused of perversion of law because he did not work on 816 cases (proceedings on misdemeanors) between 2013 and 2015. The judge had repeatedly reported the case overload in many letters to the superior Regional Court and to the Ministry. The Regional Court decided that it was the task of the employer to remedy the problem.
} 


\section{Prosecutor General}

Efforts to change the election procedure of the Prosecutor General are taking two directions; to make it possible for candidates who are not prosecutors by profession to participate in the procedure and to amend the Constitution by introducing a qualified majority (three-fifths of all members of the National Council). The possibility to recall the Prosecutor General is also under consideration and will address cases when he or she ceases to exercise his or her office properly, honestly, independently and impartially.

\section{Conclusions}

Finally, although it could be mentioned also in the beginning of this section, about the reasoning behind the actual calls to reforms the judiciary. They are looking like "reforming the reforms" (which are ongoing since 2000 when the Acts on Judges and Courts have been introduced, followed by recodifications in Criminal Law and Criminal Procedure in 2005). The Specialized Criminal Court is in life since 2009 (established in 2003 as the Special Criminal Court), and it is cooperating with the Office of the Special Prosecution in matters belonging to its competence: corruption, organized crime and crimes of constitutional authorities. But both institutions did not acquit itself very well, and their decisions at least from the last decade are even running in the opposite direction. ${ }^{34}$

The need of a Supreme Administrative Court has been discussed more times (last time in 2006). ${ }^{35}$ Now it is a little bit late, because the concept of the judicial system should be thoroughly exercised at the very beginning - in 1992 (that time the powers of the expected Supreme Administrative Court could be outbalanced with those of the Constitutional Court, and other specialized courts, if needed, could be set up, too). I would like to add that in my opinion the personal element had failed - even people appointed to the highest positions. Open efforts to dominate also the third power by the leading political parties have been successfully undertaken. Anyway, this makes the reform to improve the quality of justice, to strengthen the conditions of the choice of judges and prosecutors urgent, as an ultimate step to take the judiciary - in a state under the Rule of Law - seriously.

\footnotetext{
34 In addition to the part on "Recent files in Slovakia" mentioned before: This development currently (during the last decade October 2020) ended in taking into the custody the person of Specialized Prosecutor (accused of taking bribes, organizing criminal groups, abuse of powers), but also the former Prosecutor General, and Judges of the Supreme Court.

35 E. Valko, Reforma súdnictva v Slovenskej republike, Bratislava 2006, pp. 1-46; Ernest Valko was the first president of the Constitutional Court of the Czech and Slovak Federative Republic, who was assassinated in 2010.
} 


\section{Literature}

Alexy R., Constitutional Rights and Constitutional Review, www.pravvni-edu.rs/conference/2014.1 0.24\%Fundamental\%20Rights/Alexy.pdf (accessed: 2020.08.01).

Bacon F., Of Judicature LVI. The Essays or Counsels, Civil and Moral, www.authorama.com/essaysof-francis-bacon-56html (accessed: 2020.08.01).

Barak A., Judicial Discretion, New Haven 1989.

Borkin J., The Corrupt Judge. An Inquiry into Bribery and Other High Crimes and Misdemeanours in the Federal Courts, New York 1962.

Bröstl A., "At the Crossroads on the Way to an Independent Slovak Judiciary" [in:] Systems of Justice in Transition - Central European Experience since 1989, eds J. Přibáň, P. Roberts, J. Young, Hampshire 2003.

Bröstl A., "O ústavnosti ústavných zákonov" [in:] Metamorfózy práva ve střední Evropě. Zborník z mezinárodní konference ve Znojmě 2008 (Metamorphoses of the Law in Central Europe. Collection of Papers from an International Conference in Znojmo 2008) eds H. Jermanová, Z. Masopust, Praha-Plzeň 2008.

Coke E., https://oll.libertyfund.org/pages/coke-sir-edward-1552-1634 (accessed: 2020.08.01).

Dworkin R., "The Judge's New Role: Should Personal Convictions Count?" [in:] International Journal of Criminal Justice 2003, vol. 4.

Essays of Michel de Montaigne, ed. W.C. Hazlitt, trans. Charles Cotton, London 1877.

Hamilton J., Madison, J., Jay J., The Federalist American State Paper, Chicago 1955.

Hesse K., Grundzüge des Verfassungsrechts der Bundesrepublik Deutschland. 20. Auflage, Heidelberg 1999.

Kühn Z., "Ideologie aplikace práva v době reálného socializmu (The Ideology of Application of Law in the Era of Real Socialism)" [in:] M. Bobek, P. Molek, V. Šimíček, Komunistické právo $v$ Československu. Kapitoly z dějin bezpráví (Communist Law in Czechoslovakia. Chapters from the History of Lawlessness), Brno 2009.

Limbach J., Im Namen des Volkes. Macht und Verantwortung der Richter, Stuttgart 1999.

Montesquieu Ch., Ouevres completes, Paris 1875.

Müller-Graff P.C., "Zur Geschichte der Formel 'Im Namen des Volkes'”, Zeitschrift für Zivilprozessrecht 1975.

Rohárik P., “Ústavné garancie nezávislosti súdnej moci”, 5 Justin 1999, no. 2.

Roznai Y., Unconstitutional Constitutional Amendments. The Limits of Amendment Power, Oxford 2017.

Sharan P., Comparative Government and Politics New Delhi 1976.

Thoma R., "Die juristische Bedeutung der grundrechtlichen Sätze der deutschen Reichsverfassung im allgemeinen" [in:] Grundrechte und Grundpflichten der Reichsverfassung. Bd. 1, ed. H.C. Nipperdey, Berlin 1929.

Ulč O., The Judge of a Communist State, Ohio 1972. 


\section{Summary}

\section{Alexander Bröstl}

\section{On the Third Power: Taking Independence of the Judiciary Seriously}

The article deals with the problem of the independence of the judiciary from a historical point of view (subordination of the judicature to the royal will in the $17^{\text {th }}$ century in England, examples of the two rival-judges, Francis Bacon and Edward Coke). Then it focuses on the historical background and guarantees of an independent judiciary in former Czechoslovakia, and in contemporary Slovakia. It concerns the judicial reform ready to be introduced in the Slovak legal order by 2021 with the aim to renew the credibility of the judiciary (courts and prosecution offices). Proposed legal measures are presented (security examinations, new property declarations, crime of perversion of justice committed by judges). New constitutional amendments have to do with the election of the candidates for judges of the Constitutional Court in the National Council, and the establishment of a Supreme Administrative Court.

Keywords: independence of judiciary, corrupt judges, judicial reform, new legal measures

\section{Streszczenie}

\section{Alexander Bröstl}

\section{O trzeciej władzy: traktując niezależność sądownictwa poważnie}

Artykuł poświęcony został problematyce niezależności sądownictwa. Autor przedstawia to zagadnienie z perspektywy historycznej (podporządkowanie sądownictwa woli królewskiej w XVII wieku w Anglii, przywołanie poglądów dwóch rywalizujących sędziów Francisa Bacona i Edwarda Coke'a), jak również dokonuje analizy gwarancji niezależnego sądownictwa w byłej Czechosłowacji i we współczesnej Słowacji. Artykuł dotyczy także reformy sądownictwa, która ma zostać wprowadzona do słowackiego porządku prawnego w 2021 r. w celu przywrócenia wiarygodności wymiaru sprawiedliwości (sądów i prokuratury). Autor przedstawia proponowane w ramach reformy środki prawne (badania bezpieczeństwa, nowe oświadczenia majątkowe, przestępstwo przeciwko wymiarowi sprawiedliwości popełniane przez sędziów). Nowe zmiany w konstytucji dotyczą sposobu wyboru kandydatów na sędziów Sądu Konstytucyjnego w Radzie Krajowej oraz powołania Naczelnego Sądu Administracyjnego.

Słowa kluczowe: niezależność sądownictwa, skorumpowani sędziowie, reforma wymiaru sprawiedliwości, nowe środki prawne 